\title{
Local natural resource curse and sustainable socio-economic development in a Russian mining community of Kovdor
}

\author{
TUOMAS SUUTARINEN
}

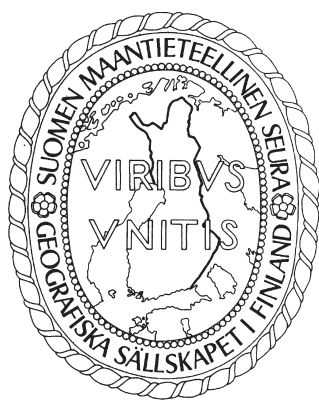

Suutarinen, Tuomas (2015). Local natural resource curse and sustainable socioeconomic development in a Russian mining community of Kovdor. Fennia 193: 1, 99-116. ISSN 1798-5617.

Natural resource extraction forms the backbone of the Russian economy and characterizes the majority of regions and communities in the Russian North. The long-term socio-economic sustainability of natural resource extraction in resource abundant countries has been questioned and discussed in various social sciences with the resource curse theory, which, however, is understudied on the local level. This study creates a local resource curse theory that is based on the basic idea that there are negative consequences to sustainable socio-economic development as a result of the resource curse. The paper seeks to explain how the current use of natural resources presents obstacles to the sustainable socioeconomic development of resource communities. The local resource curse theory approaches the unsustainability of local resource-based development using eight elements, which define the structural and attitudinal consequences of resource-based development for resource communities.

Using this theoretical framework, this study analyses the socio-economic sustainability of resource-based development in the peripheral mining community of Kovdor, located in the Murmansk region. The case study is based on survey results conducted by the author in Kovdor in 2010. The data is analysed with quantitative methods. This paper presents a new approach for understanding the resource curse on the local level. The paper argues that the local resource curse theory is competent for explaining the unsustainability of resource extraction as the basis of local development. The study demonstrates that structural and attitudinal consequences of resource-based development are important for understanding about the negative consequences of resource-based development for sustainable long-term local socio-economic development.

Keywords: resource curse, mining community, sustainable development, Russia, Kovdor, quantitative methods

Tuomas Suutarinen, Department of Geosciences and Geography, PO Box 64 (Gustaf Hällströmin katu 2), 00014 University of Helsinki, Finland. E-mail: tuomas.suutarinen@helsinki.fi

\section{Introduction}

The basis of the Russian economy is the extraction and export of natural resources, which were the backbone of Russia's rapid economic growth in the 2000s, after the economic crisis of 1998 (Bradshaw 2006; Gaddy \& Ickes 2013: 309). Northern Russia's resources contribute approximately $20 \%$ of Russia's annual GDP (Foxall 2014: 94). Oil and gas in particular have formed the core of the Russian economy accounting for about two thirds of Russia's total export revenues and almost half of federal budget revenues (Ahrend 2008: 6; Gaddy \& Ickes 2013: 310). Moreover, oil and gas produce approximately $11 \%$ of Russia's total GDP (Gaddy \& Ickes 2013: 310). Dependency on natural resource extraction is particularly characteristic of regional economies in the Russian North', where the extraction of natural resources has historically shaped the region's economic culture (e.g. Tynkkynen 2007). 
The era of economic growth in the 2000s strengthened the economic and symbolic meaning of natural resources as accelerators of Russian economic growth whilst limiting the degree of economic diversification (Gaddy \& Ickes 2010: 307). Hence, modernization and diversification have been key aspirations of the Russian economic agenda since 2007 (Connolly 2011: 428, 431). The crisis of 2008-2009 in particular highlighted the need for diversifying Russia's economy; the economic modernization programme of the then president Dmitry Medvedev in 2009 was a response to this need (IFAP 2008; Medvedev 2009). However, instead of a new drive to promote economic diversification after this crisis (Foxall 2014: 98-99), economic diversification was limited. The trend of economic diversification has been even negative in some regions of Russia, such as the Murmansk region in the 2000s as the reliance on traditional industries has increased (Didyk \& Riabova 2012: 240). Nevertheless, the natural resource-based economy has brought benefits for the short-term economic development of Russia, which was boosted by the rise in world market prices for natural resources in the 2000s (Ahrend 2008; Connolly 2011: 428). However, the vulnerability of Russia's resource-based economy has been shown in late 2014 after the falling oil price in the world markets. Nevertheless, according to Gaddy and Ickes (2010: 307), Russia would have been more vulnerable to the economic crisis of 2008-2009 if it had targeted economic diversification instead of promoting the resource-based economy in the 2000s. Hence, economic diversification is not necessarily crucial from the point of view of sustainable socio-economic development. However, regardless of the benefits, the decade of growth in the 2000s has also prolonged the fundamental problems of the Russian economy's "resource path" (Ahrend 2008; Connolly 2011: 428).

In Russia, the problem of economic diversification is an acute concern at the regional and local levels, especially in communities where the local economies are based on the extraction and export of natural resources. In the single-industry towns of the Russian North the problem of economic diversification is especially challenging as the relatively big populations found in remote areas of the North need alternative employment to sustain the future existence of their towns. The towns in the Russian North deal with the problem of modernization of their industrial enterprises and restructuring of their economic and social spheres (Pilyasov
2013: 3; Suutarinen 2013). Hence, resource-based development in single-industry towns in the Russian North forms a geo-economic risk for their sustainable development (Anokhin et al. 2014).

The unbalanced economic development of countries and regions, where the economy is based on the extraction and export of natural resources with a low level of added value in the manufacturing process, has been discussed among the scholars of various fields from economic sciences to geography under the term resource curse (e.g. Kim 2003; Davis \& Tilton 2005; Bradshaw 2006; Humphreys et al. 2007; Tynkkynen 2007; Travin \& Marganiya 2010; Van der Ploeg 2011) and staple thesis ${ }^{2}$ (e.g. Schmallegger \& Carson 2010; Carson \& Carson 2011). However, whether the natural resources of a certain country, region or community form a resource curse depends on the overall institutions and policies related to natural resource extraction (Wright \& Czelusta 2004; Rosser 2006; Ahrend 2008: 3, 7-8). Therefore, natural resources can be both a blessing and a curse for the development of resource economies at both local and state levels (Van der Ploeg 2011). Resource-based development is a questionable option for the sustainability of the economic future of a country as the dependency on extraction makes the economy vulnerable to changes in raw material prices and any crisis associated with such price movements (Bradshaw 2006: 725). Moreover, resource-based development often leads to Dutch Disease, whereby the growth of revenues in the resource sector accelerates the inflows of labour and capital from the production sector to the resource sector (Scherbak 2010: 50). Moreover, a resourcebased ideology is a hindrance to structural changes that could boost the diversification of the economy (Carson \& Carson 2011: 375). Therefore, natural resources are not necessarily a blessing that may bring prosperity to a region or locality, but can also be a curse which presents obstacles to alternative forms of development and a more rational use of existing resources. Russia in particular has been stigmatized as a country where the so-called "resource curse" has had and continues to have a significantly negative impact on its development (e.g. Sachs \& Warner 2001; Ahrend 2005; Åslund 2005; Tynkkynen 2007).

Despite the studies of resource-based development as a curse for state and regional economic development (e.g. Kim 2003; Bradshaw 2006; Travin \& Marganiya 2010), only a few studies dis- 
cuss the resource curse as a local phenomenon, such as Tynkkynen (2007), from a geographical point of view, and Borge et al. (2013), from an economic point of view. Studying the natural resource curse at a local level presents a challenge in that one has to adapt state- and regional-level theories to the local level. On the state level, the resource curse impacts in various ways, such as promoting policies that support the interests of the main resource industries instead of policies that promote a more diversified economy. However, on a local level, in resource communities, where the opportunities for diversification into alternative industries are limited, the resource curse theory has to be approached from a different viewpoint as one has to explain how the current way of resource extraction represents a challenge for sustainable socio-economic local development. This idea encourages the author to hypothesize that local level obstacles to sustainable socio-economic development, which could benefit from the comprehensive use of the human, natural resource and environmental potential of the community, can be explained by a modified version of the resource curse theory. While the usual economic resource curse theories are based on the negative economic consequences of a resource-based economy, such as how resource extraction produces excessive rent, this paper seeks to define the structural and attitudinal consequences of resource-based development for resource communities (e.g. Tynkkynen 2005, 2007; Schmallegger \& Carson 2010; Carson \& Carson 2011).

This paper contributes to resource curse theory by creating a theoretical framework for what we might call the local resource curse. The paper is based on the main idea of the resource curse, namely, that it has a negative impact on comprehensive sustainable socio-economic development across various spatial scales. The paper develops the theory of the local resource curse by combining elements from the theories of the resource curse and the staple thesis. This paper will emphasize that the rethought local resource curse theory is useful for understanding the dimensions of unsustainability of resource extraction as the basis of local development. This paper will further demonstrate that the resource curse theory is suitable to expand from the state and regional level discussion to the local level. Moreover, this paper will define the criteria by which resource curse theory is useful to study on local level. This study understands sustainable socio-economic development by the following criteria: (1) the utilization of local resources based on long-term planning and diverse visions of the local economic potential; (2) the utilization of local natural resources without damaging the longterm potential of local alternative industries and local living environment; and (3) the utilization of local resources with respect for the social aspects of local sustainable development.

The theoretical framework is used in an analysis of the local resource curse in a case study of the peripheral resource-based mining town of Kovdor, located in the western part of the Murmansk region (Fig. 1). The case study seeks to analyse how the elements of the local resource curse theory can explain the unsustainable use of local resources in the case study town. The case study is based on a survey that was conducted by the author among the residents of Kovdor in September 2010. The survey mainly involved workers of the town-constituting enterprise Kovdorskii GOK (later KGOK). The data was analysed quantitatively using frequency measurements for the numerical data.

The study continues as follows: in the second section, the theoretical framework of the paper is created. The third section analyses the case study together with the survey from the point of view of local resource curse theory and the fourth section discusses the findings of the study. Finally, the fifth section draws the conclusions of the study.

\section{Local resource curse theory}

In this chapter resource curse theory is modified in order to be applied to the local level. This chapter seeks to define different elements of the local resource curse. Then these different elements are discussed in detail.

Local resource curse theory serves as a tool for identify the elements that describe the incomplete nature of local development, which could be improved by changes in the interrelations between and policies and practices of the state, the region, resource firms and local actors in the community. The local resource curse theory adapts parts of the staple thesis theory due to several similarities with the general characteristics of staple-based economies, as discussed recently by Schmallegger and Carson (2010: 204-205) as well as Carson and Carson (2011). These characteristics can be used as local level factors to explain the obstacles to sustainable socio-economic development in peripheries with resource extraction industries. 


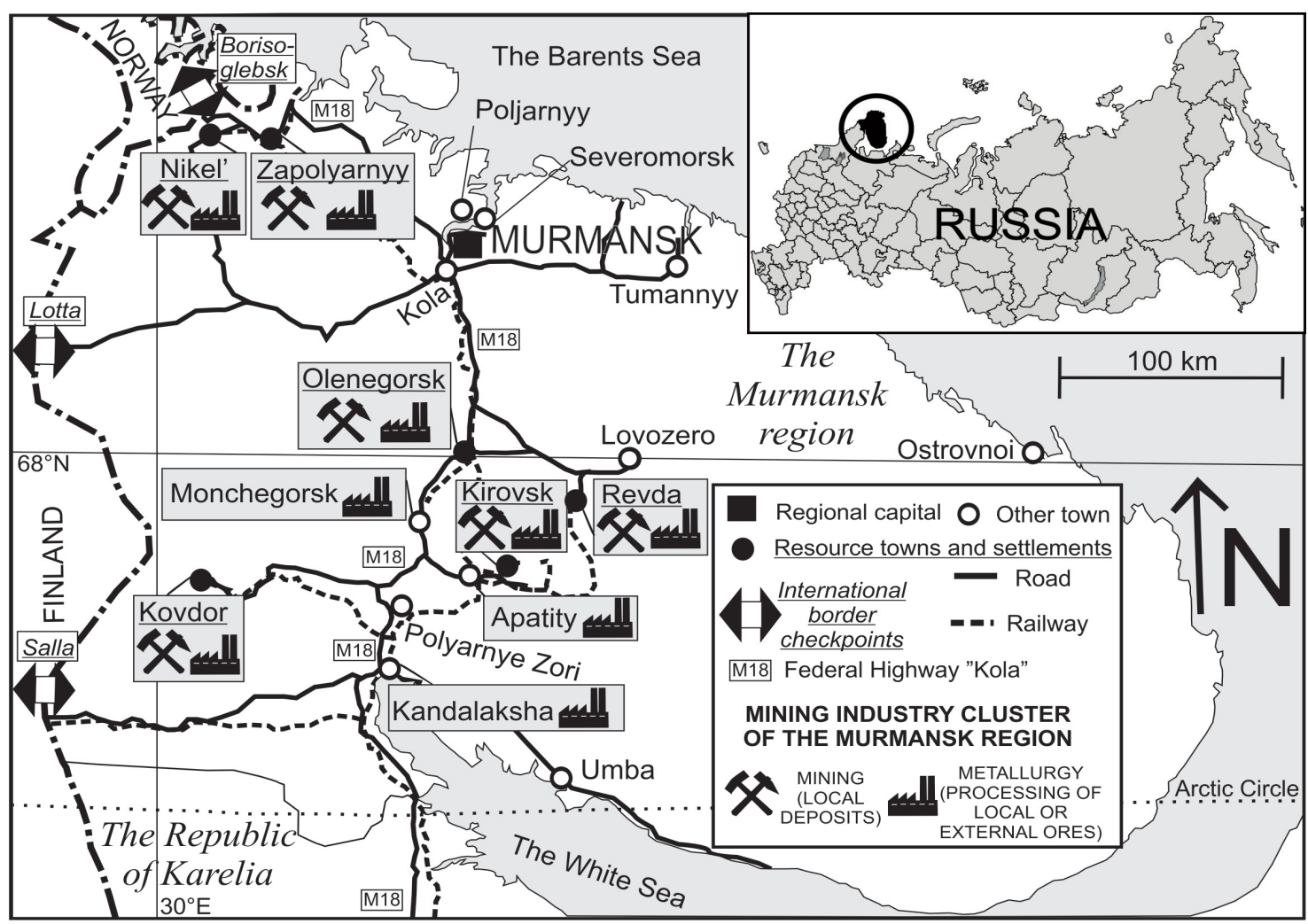

Fig. 1. The Murmansk region and its resource and industrial towns.

The staples thesis describes the formation of structural dependency on natural resources in staple-producing regions (e.g. Barnes 2005). Several of the main characteristics of the staple thesis are suitable for inclusion in the local resource curse theory. However, not all the staple thesis arguments, such as the dependency of the resource communities on external capital and labour (Schmallegger \& Carson 2010: 204-205), are currently characteristic of those industrial Russian peripheries, which were industrialized in the Soviet period, such as the Murmansk region. In the course of Soviet industrialization such regions were populated by newcomers, which have since acquired a more permanent presence (Bolotova \& Stammler 2010).

In resource curse theory, based on the previous findings of scholars, the elements of the local resource curse are classified in eight categories, all of which describe the negative impact and characteristics of a resource-based economic culture on sustainable socio-economic development at a local level (Fig. 2).

\section{Local resource curse: resource-derived elements}

The first element (E1) of the resource curse is the unsustainable and unpredictable development of resource states and regions caused by the volatility of resource prices (e.g. Bradshaw 2006: 725; Schmallegger \& Carson 2010: 204). On the local level the dependency of resource communities on the main resource-extracting firms, which are vulnerable to external market forces and to the volatility of resource prices on world markets, impacts on the development of these resource communi- 
ties and on their local revenues. In turn, the social development of these resource towns is dependent on these revenues. In Russia's resource communities the local budgets are dependent on the competency of main enterprises. Their direct tax payments alongside with indirect revenues form the basis of local budgets (e.g. Kovdorskii raion 2011). Therefore, the consequences of the global volatility of natural resource prices are greater for local resource communities than they are for a state or a region. Moreover, in Russia, resource industries employ more workers than they do in Western countries. Therefore, the volatilities of resource industries have consequences to relatively populous resource communities, and thus present massive regional concerns in natural resource dependent regions. However, the impact of the volatility of resource prices depends on how and at what level resource rents are collected and redistributed.

During economic booms, the prosperity provided by a leading resource industry satisfies the community and its decision makers, which however has the unfortunate effect of discouraging them from diversifying. Strategies for economic diversification in resource-based regions and communities only receive interest when boom turns to bust (Carson \& Carson 2011: 374). Then, the policies for improvements are usually ad hoc in nature
(Tykkyläinen 2010: 257) and only last until the next boom arrives.

According to the main argument of the resource curse theory, in economies rich in natural resources economic underperformance is common when compared to economies with limited natural resources (Sachs \& Warner 2001). The "paradox of plenty" (Karl 1997) and resource abundance (Bradshaw 2006) demonstrate how states and regions with huge natural resources usually use their resources inefficiently and extensively (E2). Moreover, the economic policies of resource-based states and regions concentrate on their main resources, which they then export (Tynkkynen 2005: 8). Therefore, the use of the human capital and other natural resources of such resource-based communities are limited (Tynkkynen 2007: 861). The "paradox of plenty" also impacts on the internal development of the main export industry. For example, the utilization of new deposits of the main exported resource is delayed as long as the old deposits produce profits thereby creating an illusion of sustainability (Bradshaw 2006: 725). Moreover, local resource enterprises pay minimal attention to the development of innovations and maintain passive policies rather than adopt changes. Additionally, state-owned and state-controlled enterprises are less innovative and less efficient in
Fig. 2. Elements of the local resource curse.

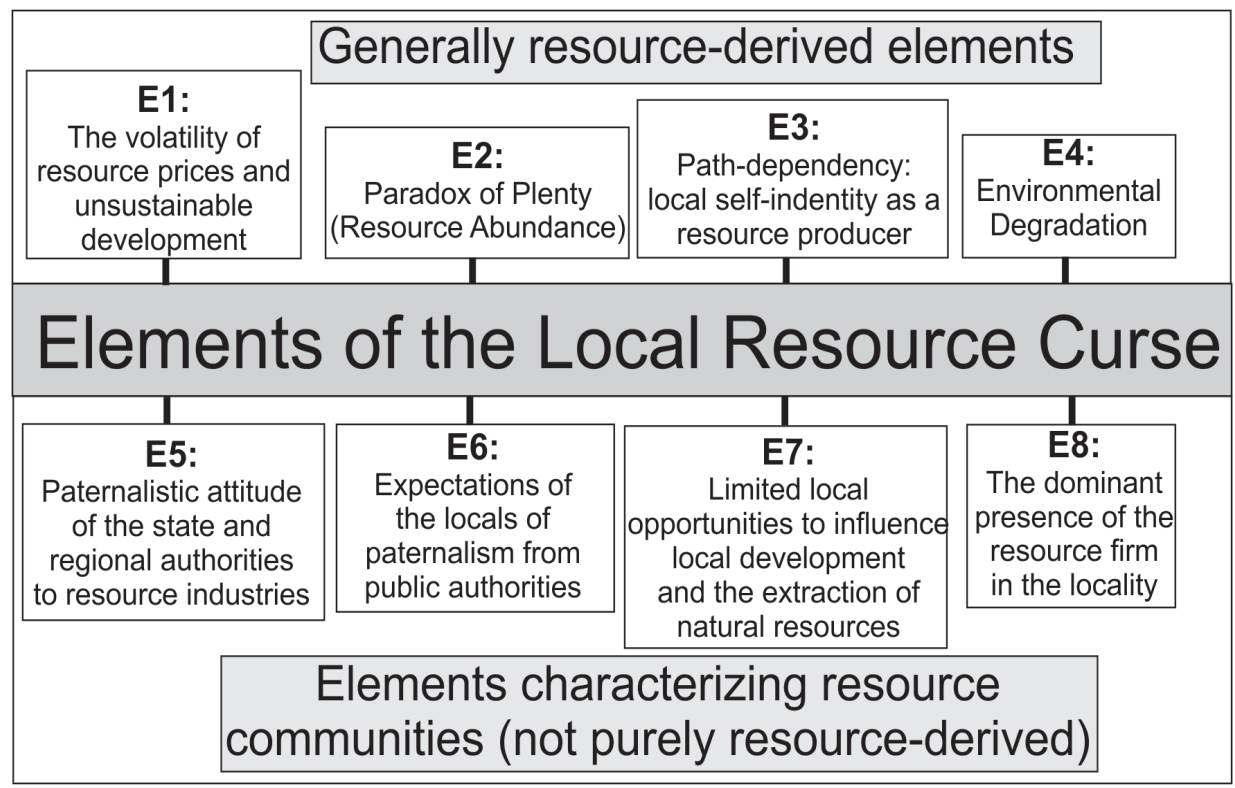


comparison with private companies (Ahrend 2008: 5). However, the "paradox of plenty" at local level presumes that local actors play an active role in the utilization of their natural resources. When the utilization of local resources is controlled by external actors, such as the state and external enterprises, then the likelihood of locally improving the utilization of local natural resources is limited.

Furthermore, when the natural-resource industry is considered stable and satisfactory, it discourages the locals from thinking about alternative economic paths for their community, which is reflected, for example, in the low level of entrepreneurial activities in resource-based communities (Tynkkynen 2007: 861; Carson \& Carson 2011). These findings support the argument that, at the local level, there is (1) lack of further investment in the main resource business, which leads to a deterioration of production due to the ageing of the natural resource deposits, (2) lack of diversification and spin-offs within the main industry, and (3) lack of economic diversification into other potential sectors of the economy, which could utilize more fully other local natural resources of which there may be abundance. At a local level, resource abundance is also represented with "crowding out", that is, when resource exploitation offers better returns to the factors of production, and so raises their price to uncompetitive levels for other economic activities (e.g. Sachs \& Warner 2001).

Economic development based on the export of natural resources supports the formation of path dependency, ${ }^{3}$ where the local culture and economic policies are based on producing resources for export (Schmallegger \& Carson 2010: 201202; Carson \& Carson 2011: 373-374). Therefore, the path dependency of resource-based communities merely strengthens the local self-identity and inner culture as a resource producer (E3), which hinders the development of alternative industries (Carson \& Carson 2011: 373). Moreover, resourcebased communities exhibit a tradition of certain professions and lack of diversified skills. Therefore, resource communities have limited human capacities, which could be used in the development of alternative industries (Carson \& Carson 2011: 375). The historical way of development hinders the development of alternative industries (Carson \& Carson 2011) and supports an apathetic attitude to change. This passivity and lack of innovative thinking are common in the regional and local administrations of resource-based communities and regions (Tynkkynen 2007: 862), and causes attitu- dinal obstacles to change. The local resource path supports the formation of "resource fatalism" in the community, which is reflected in lack of belief in alternative development paths.

Environmental degradation (E4) is an obvious local level consequence of extensive resource extraction. It has a direct influence on the quality of life in resource communities. Moreover, environmental degradation hampers other land use activities around the resource extraction areas, such as the traditional land use of indigenous people. This is evident especially in the oil and gas regions of the Russian North where the reindeer herding of indigenous people often collides with resource industries (Stammler \& Peskov 2008). However, the consequences of environmental degradation for sustainable socio-economic development vary between different resource communities. In resource communities with obvious diversification potential, for example, into tourism, environmental degradation can hamper these opportunities. However, if there was no settlement before resource extraction began, the community was created because people came to work in the local industry, and they have got used to the fact of a certain level of environmental degradation in their community. For workers in the main resource industry, their self-identity as locals has been formed through their work in that resource industry, which has occupied a central position in their lives, and environmental degradation is to a certain extent tolerated and taken as 'normality', that is, as an inevitable consequence of the resource industry (Bolotova 2012: 667).

\section{Local resource curse: other elements}

In countries where the extraction of natural resources plays a significant role in the economy, the state and regional authorities usually have a paternalistic attitude towards resource industries (E5), which is reflected in the accumulation of external and public investment in the main resource industry (Schmallegger \& Carson 2010: 205). This paper defines paternalism as preferential and subsidization policies on the part of the public authorities towards the resource industry of a community, which also has indirect positive economic consequences to its residents. However, as the resource community is treated as a resource producer and the well-being of the resource industries are the main interest of the state, it often leads to the social degradation of the community, because the resource industry is the primary concern of higher 
governmental levels instead of the social well-being of the community. Public authorities protect the resource industries from the negative impacts of global market dynamics and invest in them and their infrastructure in order to attract private investment (Carson \& Carson 2011: 374). However, these investments are controversial from the viewpoint of sustainable development in the resource communities. According to Carson and Carson (2011: 373), investment in supporting and subsidizing the dominating resource industries could be used to support economic diversification in alternative industries.

In Russia's resource communities, the state and regional authorities invest mainly in order to develop their resource industries. This is particularly true of investment policies during periods of crisis in the natural resource sector. The paternalistic attitude of the public authorities in Russia is often justified by arguing that the resource industries are strategic industries, whose existence needs to be secured. These subsidies are usually the result of ad hoc policies to solve the immediate negative impacts of a crisis and are often preferred to investments in alternative industries that could secure long-term sustainable economic development (Blakkisrud 2006: 38; Tykkyläinen 2010: 257). These ad hoc policies seek to maintain the stability of resource industries without making significant improvements in their efficiency (Tykkyläinen 2010: 257).

Whilst the role of public authorities as paternalistic care-takers of such communities usually manifests itself indirectly through their investments in resource firms, it means that the social development of resource communities is left as a secondary priority (Suutarinen 2011, 2013). Therefore, resource firms are partly responsible for providing social services and they are treated as paternalistic actors in the resource communities. In the Soviet period, resource firms in resource communities had an important role as providers of several paternalistic services to communities and several privileges for their workers (Kortelainen \& Nystén-Haarala 2009: 151-152; Prokhorova 2014). The transfer of social responsibilities of the Soviet system from the enterprises to local administrations began during perestroika in the late 1980s and accelerated after the collapse of the Soviet Union in the 1990s (Kortelainen \& NysténHaarala 2009: 152; Eilmsteiner-Saxinger 2011). However, local administrations were financially unable to respond to their new duties. Therefore, to maintain social stability in the communities, re- source firms are in some sense forced to maintain such services in resource communities in the absence of other actors and the incompetence of local administrations (Kortelainen \& Nystén-Haarala 2009: 151-152; Reisser 2013: 17), but also do so on their own initiative (Melin 2005; Kortelainen \& Nystén-Haarala 2009: 155). During Putin's era, the demands of social commitments from the state to major enterprises in single-industry communities have grown in comparison with the 1990s (Fortescue 2009).

The historical path of resource regions and communities under the control and care of the state has led to a culture of dependency (Carson \& Carson 2011: 375), and created local expectations of public subsidizes and paternalism (E6) from the state and the resource company. The resource communities' reliance on resource corporations, in particular their role in the commercialization of locally extracted materials, limits the independent entrepreneurial aspirations of the locals (Carson \& Carson 2011: 375). Residents' expectations that the state will, as it has in the past, subsidize the main industry of their community may also engender similar expectations about state paternalism for any other industries that may arrive in the region. In any event, this merely promotes long-established views that it is the state, not companies, that is ultimately responsible for the welfare of such communities (Carson \& Carson 2011: 375).

In Russia, the historical legacy of the state as a care-taker of resource communities in the Soviet era forms the basis for the paternalistic expectations of their residents. Among the residents of resource communities there is a widespread view that the resource enterprise and high-level public authorities should provide key benefits and services for the resource community. Moreover, the self-esteem of the residents of the resource regions and long-distance commuting workers of the Russian North as the national heroes and feeders of the nation (Rautio \& Round 2008: 113; Eilmsteiner-Saxinger 2011) creates expectations of paternalism and subsidies from higher authorities instead of the willingness to move to economically more viable places. The existence of paternalistic expectations on the part of residents and firms (E6), and the paternalistic attitudes of public authorities towards resource industries (E5), are widespread in resource communities and are obstacles to sustainable local development. However, paternalistic expectations are common not only in resource communities, but 
are common in Russian single-industry towns and in Russian society as a whole (e.g. Melin 2005; Kortelainen \& Nystén-Haarala 2009).

The staple thesis discusses how resource regions are under the economic and political domination of higher governmental levels, which dominate planning and decision making with regard to local issues and politics (Schmallegger \& Carson 2010: 203). The state prolongs this domination because it relies on the exports of materials produced by resource regions and communities (E7). Moreover, also the dominance of external resource corporations and their policies in the resource communities restrict local opportunities to influence local development. Local firms usually operate at the beginning of the production chain and their products are processed in other regions (Carson \& Carson 2011: 374).

In the resource peripheries of Soviet Russia, local planning and decision making was dominated by higher governmental levels and state-owned resource corporations (Rautio 2003: 63; Tynkkynen 2005: 3; Petrov 2008: 146). After the decentralization policies of the 1990s, the importance of the Russian state in the resource peripheries increased in the 2000s as a result of recentralization policies and the role of the Ministry of Regional Development in controlling regional development with centralization policies that resemble Soviet era regional policies (Blakkisrud \& Hønneland 2006: 13; Tynkkynen 2007: 853). However, the ability of these new policies to bring socio-economic sustainability to the local level is questionable as the state planning has been insufficient for solving the socio-economic problems of the Russian North. After the collapse of the Soviet Union, the policies of the Russian state towards the communities of the Russian North have been ad hoc and have been directed at addressing various immediate crises (Blakkisrud 2006: 38; Tykkyläinen 2010: 257). However, the limited role of locallevel planning characterizes not only resource communities but all of the communities and regions of Russia in their relationship with the centre (Didyk 2012). The municipal finance system is a major obstacle to local self-governance development in Russia (Barasheva 2011). Tax reforms in the beginning of the 2000s decreased local fiscal autonomy (Barasheva 2011). In general, the local budgets are dependent on the vertical system of regional and federal authorities and transfers from regional budgets (Barasheva 2011; Didyk 2012).

The dominant presence of resource firms in resource communities promotes resource-led think- ing and the interests of the resource firm in local development (E8) instead of economic diversification into other industries. Therefore, the interests of the main resource extracting industry and those of other industrial fields often conflict, and this is particularly the case when it comes to the use of nature (e.g. Tynkkynen 2007). This leads to opposing priorities between, for example, resource industries and tourism concerning the use of land in natural resource communities, and to underestimating the potential of alternative industries (Tynkkynen 2007: 863; Kauppila et al. 2009: 427). Therefore, resource peripheries are contested spaces (Hayter et al. 2003). Moreover, other activities, such as agriculture and land use activities of indigenous people, such as reindeer herding, have also colliding interests with the resource industries. Conflicts between interests of different stakeholders might arise when the extraction of natural resources appears on territories that are used by indigenous people on their traditional livelihoods (Stammler \& Peskov 2008). However, there are cases where the local resource industries have formed a culture of dialogue between the local indigenous people (Stammler \& Peskov 2008).

Resource communities have often limited interaction with their surrounding areas. Therefore, they have a relatively "closed character". According to Humphreys et al. (2007: 4), the production of natural resources can take place for the most part independently from other economic processes and industrial sectors and is therefore relatively 'enclaved'. The closed character of resource communities does not hamper the main resource industry directly, but creates obstacles for other industries such as tourism or small- and medium-sized businesses (SMEs), which would need the area to be more open. The closed historical path of resource communities has fostered suspicious attitudes towards outsiders, which hampers, for example, attempts at economic diversification into other industries such as tourism, which would need different forms of social capital to that required by the mining industry. Moreover, the closed culture of resource communities might make it difficult for them to attract skilled workers, the so-called creative class, who could be drivers of innovations in their main industry (e.g. Florida 2005). Nevertheless, even if official restrictions ${ }^{4}$ are removed, the "closed character" of the local culture and general attitude of the residents of such communities will not disappear rapidly. 
In Russia's resource peripheries, the specific interests of the main industry will dominate the future development of the community, which in turn will to some extent weaken the chances of diversifying the economy. Partly this is related to the "crowding out" of Dutch Disease (e.g. Scherbak 2010: 50), which means that the local resource industry offers the best source of income for local people, such as local subcontractors and SMEs. Therefore, in resource communities the locals have fewer incentives to work in alternative industries that generate smaller profits. Moreover, the interests of the main resource industry also create obstacles for alternative development by the resistance of entrepreneur aspirations of its workers (Rautio 2003: 76). Furthermore, resource industries usually employ the most innovative individuals in any given resource community (Ahrend 2008: 6). Therefore, there is lack of innovative developers who could serve as drivers of economic diversification in these resource communities.

\section{Case study: Kovdor and the local resource curse}

In this section, the findings of the case study will be presented. This section analyses how local resource curse theory can help the discussion concerning the challenges for the sustainable use of local economic potential. The section begins with the introduction of Kovdor as a resource town. This is followed by the empirical part of the paper, which is based on an analysis of the survey data. The survey was conducted by the author in Kovdor (see Fig. 1) in co-operation with the town-constituting enterprise KGOK in September 2010. The used questionnaire detected the views held by the population on the development perspectives and viability of Kovdor. Employees of the worker's union distributed the questionnaires to the respondents. Hence, the role of the union as a co-operation partner, and their potential influence on the responses, has to be taken into account in the analysis of the results. The worker's union distributed 700 questionnaires, of which 356 were returned with a return rate of $51 \%$. Of the survey's 356 respondents 298 were employed by KGOK while the others were employed in a variety of professions in other fields of the town's economy. KGOK had 3500 workers during the survey (Suutarinen 2011: 131). Hence, the 298 respondents represented $8.5 \%$ of the total work force of KGOK. $90 \%$ of the male respondents and $75 \%$ of the female respondents worked at KGOK. The age of respondents ranged between 18 and 69 years while $53 \%$ of the respondents were men.

During the survey in 2010, the number of population in the town of Kovdor was 18,800 $(17,600$ in 2014) (Moi Gorod 2014). Hence, the 356 respondents represented $1.9 \%$ of Kovdor's total population. There are no figures available of the total numbers of economically active population in the town of Kovdor. However, the whole Kovdor district including the rural settlements had 21,700 residents in the beginning of 2010 of whom 11,000 were employed in 2009 (Kovdorskii raion 2011: 14). Hence, the 356 respondents represented $3.2 \%$ of the total employed population of the Kovdor district.

The author used quantitative methods by employing frequencies measurement (SPSS program) related to the multiple-choice questions of the survey. Moreover, possible differences in views between the workers of KGOK and other residents were investigated by Chi Square test.

\section{Mining industry in Kovdor}

Kovdor is a single-industry resource town, which is dependent on its mining activities. The rapid restructuring of the 1990s after the collapse of the Soviet Union saw the end of forestry and other industries in the Kovdor district (Suutarinen 2013). Moreover, in the Kovdor district there are no conflicting interests between the land use of resource industries and indigenous people because the small local Sami population has not practiced intensive reindeer herding since the beginning of mining history of the Kovdor district. According to the former head of Kovdor district, L. Dombrovskii, the town was originally created to be a resource producer (Suutarinen 2013: 339). There is little chance of other industries establishing themselves in the town because of its remoteness. Hence, the historical development path of Kovdor as a resource community together with the liquidation of its alternative industries in the free market period of the 1990s support "resource fatalism" where resource path is viewed as the only reliable development direction of the community (E3). Moreover, the Kovdor district is rich in various kinds of minerals (Tsukerman 2012) and this abundance of resources is probably another factor in the community's resource fatalism. 
The town-constituting enterprise KGOK, which is owned by its parent company Eurochem, produces iron ore, apatite and baddeleyite concentrates. Situated at the beginning of Eurochem's production chain, KGOK is a crucial producer of apatite concentrate for the parent company, which is Russia's largest mineral fertilizer producer (Pilipenko \& Sapuntsova 2007: 19-20). KGOK was a state-owned enterprise during the Soviet era. This was followed by a period of independence in the 1990s before Eurochem took possession of KGOK in 2001-2002 (Suutarinen 2013). During the first decade of the 2000s, the number of workers in KGOK fell as a result of economic restructuring and an increase in the company's efficiency. KGOK employed around 3,800 workers in 2012 (MinEc 2012). In 2009, the company employed $36 \%$ of the economically active population of the town (Kovdorskii raion 2011: 15). Moreover, KGOK is also an important provider of social services in the community (Khibiny.com 2012). The economic crisis of 2008-2009 led to a small fall in the number of KGOK's workers, but since then the number of workers has almost returned to pre-crisis levels (MinEc 2012). Eurochem even carried out some investment projects during this period of economic stagnation in Russia (Khibiny.com 2010). As a town Kovdor is directly dependent on the financial condition of the main enterprise KGOK (Kovdorskii raion 2011: 46). More than $70 \%$ of the budget of Kovdor's district consisted of tax payments from KGOK and the local budget is totally $90 \%$ dependent on the revenues of KGOK (Kovdorskii raion 2011: 24, 46).

Kovdorslyuda, the second mining firm in Kovdor, experienced serious problems after the collapse of the Soviet Union. It produces vermiculite, phlogopite and pegmatite. After the emergence of the market economy, Kovdorslyuda's problems intensified with high production costs, obsolete equipment and technology, reduced volumes of production and extremely high prices for energy, all of which made the company unprofitable (Maksheeva 2010; Yusupova 2013; 51rus.org 2014). Several of the problems concerning the lack of profitability of Kovdorslyuda are too deep to be solved with investment. In comparison with KGOK the lack of a prosperous owner as parent company has also prevented Kovdorslyuda from overcoming its problems. Kovdorslyuda experienced its third post-Soviet-era bankruptcy in 2014 (Bystrova 2013; 51rus.org 2014). However, organizational restructurings after these bankruptcies have allowed it to maintain part of its production (51rus.org 2014).
The regional administration of the Murmansk region has supported Kovdorslyuda despite of its unprofitability (Andreev 2009; Larichkin 2012). Moreover, the CIP document that was created by push from the state authorities targeted invest to Kovdorslyuda in spite of its unprofitable development (Kovdorskii raion 2011). Moreover, Kovdorslyuda was included among the priority investment projects of the Murmansk region in the strategy of socio-economic development of the North-West Federal district (Strategicheskoe partnerstvo "SeveroZapad» 2012). This serves as an example of development policies, which tried to improve unprofitable resource industries instead of investments in industries with better long-term prospects (E5).

The fact that decision making (E7) concerning the community and its resources is made by the state and external resource corporations, is another complication for other potential industries in Kovdor. The closed history of Kovdor (Suutarinen 2013) has not been harmful for the mining industry but is harmful for potential alternative industries, such as tourism. The border zone restrictions, which have historically created a semi-closed development path for Kovdor with restricted economic and every-day interaction with neighbouring towns (Suutarinen 2013: 331-332), have hampered alternative development paths. However, the community has not actively sought to have these restrictions lifted, firstly because these restrictions have not been harmful for the main resource industry and secondly because the locals have not been made aware of alternative opportunities (Suutarinen 2013). However, in terms of path-dependency (E3), the closed character of the community strengthens its sense of "resource fatalism" and its self-image as a resource producer instead of fostering a sense of being a more open community, which would be needed for the creation of alternative development paths for the community.

KGOK receives state subsidies for its investment projects, which promoted the economic modernization of the company. KGOK received money from both the federal and regional government to modernize its facilities and for the construction of new production units in 2013 (B-Port.Com 2013). KGOK has also been named as a strategic enterprise due to its production of baddeleyite, which is used in Russia's strategic industries (Kvitko \& Telen' 2001). Moreover, KGOK has invested in the internal diversification of its production recently (Larichkin 2012). Therefore, resource abundance (E2), which is typically represented in a one-sided utili- 


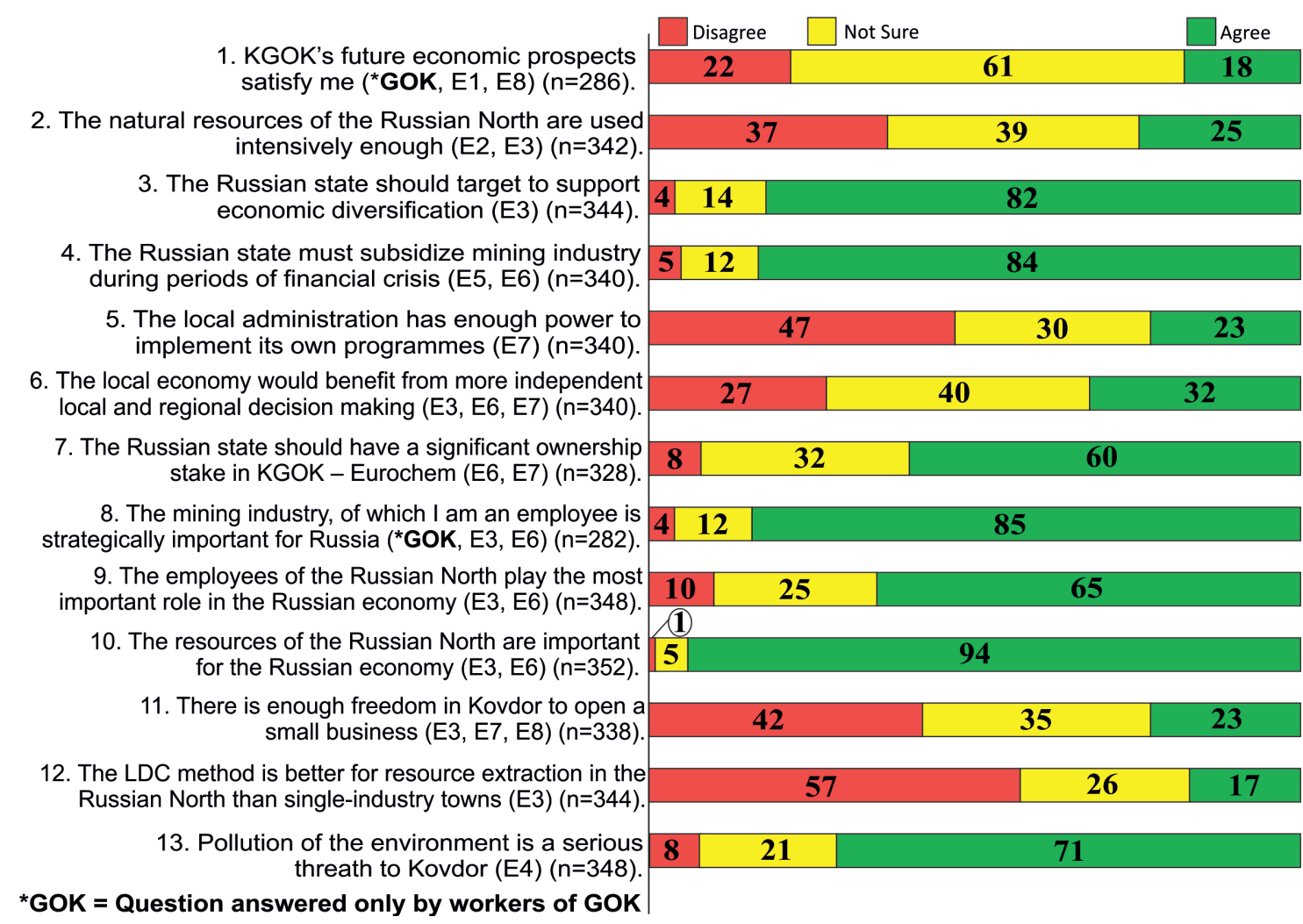

Fig. 3. Opinions of the respondents of the Kovdor survey about resource-based development in Kovdor, the Murmansk region and the Russian North (the relevance of the statements with the elements of the local resource curse indicated in brackets E1-E8).

zation of the local resource potential, does not characterize KGOK. The internal diversification of KGOK's ore production earlier in the Soviet era established a diversified development path within the company (Nash Gradostroitel'nyi kombinat 2014).

\section{Kovdor and the local resource curse according to the findings of the survey}

The survey seeks to establish how the residents of Kovdor view the town's resource-based development and its future socio-economic sustainability. This chapter attempts to establish whether the survey results support the paper's hypothesis that the "resource curse" can help to identify the locallevel obstacles to sustainable socio-economic development. The survey's results will provide further evidence of the promotion of resource-led development in the case study community's general way of thinking, which in turn creates obstacles for the overall socio-economic development of the community. The empirical study analyses the opinions of Kovdor's respondents, as expressed in their answers to the questionnaire, in so far as they relate to statements (Fig. 3) which directly or indirectly discuss the elements of the local resource curse theory. Several statements discuss various elements of the theory.

The author hypothesizes that the resource-led thinking of the community is reflected in: (1) an over-emphasis of the role of the natural resources in the development of Kovdor, the region and Russia as a whole, which reflects path-dependent thinking (E3); (2) a rejection of the alternative paths of development (E7); (3) expectations of paternalism (E6); 
and (4) resource abundance (E2), which leads to economic under-performance when compared to the full economic potential of the community.

The first statement showed how the volatility of prices in the resource-industry (E1) causes uncertainty about the future of the firm. Moreover, the statement also reflects the closed culture (E8) that prevails in the firm where news related to its economic future and new investment projects fails to be conveyed to the workers. This was also pointed out by Dombrovskii (2011), who argued that the information policy of the company towards its workers needed to improve, because the administration's optimistic expectations about the company's future are not relayed to the workers, who therefore are left instead in uncertainty about the future.

The second statement shows that a minority $(25 \%)$ of the survey's respondents agree that the intensity of the use of resources of the Russian North is satisfactory. This statement measured the residents' views concerning resource extraction. From the point of view of the "paradox of plenty" (E2), this finding shows that the efficiency and intensity of the resource utilization could be improved. However, on the other hand, this shows that resource-based development in the Russian North is supported by the residents (37\%). This in turn reflects path-dependent thinking (E3), as resource extraction is viewed as the basis for the development of the Russian North.

The third statement reveals the existence of strong expectations about the role of the state in fostering the diversification of Russia's economy. However, the fourth statement shows strong support for the idea that the Russian government should protect the mining industry in the form of subsidies during periods of financial crisis. Therefore, the survey's results reveal both a paternalistic demand (E6) for the continuation of support for the dominant resource industry (E5), which is logical from the point of view of a resource community, and support for a state-led approach concerning economic diversification in Russia. Hence, these views reflect the path-dependency of paternalistic expectations (E3, E6). However, the author has shown in a previous study (Suutarinen 2013) that the residents have little faith in the role that other industries might play in the economic future of the community. Despite this lack of belief in the prospects of economic diversification amongst Kovdor's residents, the mono-dependency of the town and the previous economic crisis have probably led to the recognition that alternative industries should be supported in Russia as a whole. Moreover, as the survey's respondents in general agree about the need for state support in diversifying the economy in Russia, the "resource fatalism" that prevails in the community does not influence the residents' general attitudes towards economic diversification in Russia as a whole.

The fifth statement reveals lack of belief in the ability of the local administration to promote local development with its own programmes. The statement tests whether the position of the local administration is strong enough to operate independently in relation to higher levels of governance (state and regional authorities) and the resource firm (E7). Only $23 \%$ of the respondents believe that the town's administration is sufficiently independent. Almost half of the respondents (47\%) agree that the local administration occupies an inferior position in relation to these other actors, which is typical in resource communities (E7). Moreover, the limited independency of the local budget is also explained by the budgetary dependency of Kovdor's administration of revenues from KGOK.

The sixth statement shows that only one third of the survey's respondents agreed that a greater degree of independence would be good for the local economy. Hence, there is general satisfaction amongst the community that it is under the control of higher organs when it comes to decision making (E7). This forms the basis for the path-dependency of paternalistic expectations (E3, E6) in the community, as the development of the community is guided by higher levels of decision making. These answers demonstrate that the residents of the community might not be aware of the potential positive consequences of increased local-level decision making. This might in turn be because of the lack of local planning hitherto (E7) and the pathdependency of the community as the subject of higher decision-making actors, such as state paternalism and the dominance of politics of external resource firms in the community. Moreover, the residents' limited belief that improvements could follow if there was greater local independence reflects the trust of the community in the Russian state and external corporations as the guarantors of satisfactory development in the town.

The seventh statement shows that majority of the survey's respondents agreed that the Russian state should have a significant ownership stake in KGOK-Eurochem. This shows that there are widespread expectations that the state should be a stable and paternalistic owner of the town-constituting 
enterprise and a guarantor of stable, resource-led development in Kovdor (E6). Moreover, the result shows a belief that external decision making related to the use of local resources would be positive for the community (E7). Therefore, resource extraction by a state-led corporation would be a satisfying option for the residents of the community.

The eighth statement shows that there is a strong belief that the field of industry in which KGOK is engaged is strategically important for Russia. This strategic self-identity can be used as an argument in support of paternalism from the state (E6), if the volatilities in world-market prices cause problems for the economic security of the company and its workers. Moreover, the ninth statement shows that the employees of the Russian North think they play the most important role in the economy of the country. Therefore, the survey's respondents can justify the necessity for paternalism (E6), given their self-image, as workers of the North, about their important contribution to the economy of Russia.

The tenth statement shows that there is almost a consensus amongst the survey's respondents about the importance of the North's resources for the Russian economy. Therefore, the residents in the community have a base for their paternalistic demands from the state towards the community (E6) on their experienced role as servants of the state as important contributors to the economic performance and security of their country and scions of the northern heroism (Rautio \& Round 2008: 113). Moreover, the statement also reveals path-dependent thinking (E3), where these resources are seen as crucial for the Russian economy. Given that the locals argue that these resources are, indeed, the basis of the Russian economy, it naturally follows that they also see themselves as having particular significance for the Russian state as resource producers. This view, which reflects the resource path of the community, is also an obstacle to the locals to seek economic diversification to industries, where exists a smaller sense of significance. Therefore, this attitude can be an obstacle for to the diversification of the economy, if alternative occupations are regarded as less significant, or as having less status, for the country.

The eleventh statement shows that $42 \%$ of the survey's respondents expressed the opinion that there was insufficient freedom for people to open alternative small businesses in Kovdor. This opinion could reflect the dominant position of the main town-constituting enterprise in the community (E8) and have a negative impact on the work- ers' aspirations when it comes to economic diversification (e.g. Rautio 2003: 76). However, it could also reflect path-dependent thinking (E3) and the idea of "crowding out", which cause inability to see possibilities for alternative businesses by almost half of the survey respondents.

The twelfth statement shows small support for long-distance commuting (LDC) in resource extraction in the Russian North. The majority of the survey's respondents support the model of a single-industry town for resource extraction, instead of the LDC method, the popularity of which has grown in remote resource locations of Russia in recent decades, especially in the oil and gas industries of Western Siberia (e.g. Spies 2009; Eilmsteiner-Saxinger 2011). This finding reveals path-dependent thinking in attitudes towards the best method of natural resource extraction in the Russian North. However, LDC in the mining of the Murmansk region is uncommon. Therefore, these attitudes are probably mostly influenced by the regional experience of resource extraction. Generally, because of support for permanent settlements, this finding shows that there is a need for local diversification in the resource communities of the Russian North in order to promote sustainable local development in permanent communities.

The thirteenth statement shows that the survey's respondents agree that pollution is a serious threat for Kovdor (E4). Therefore, the residents agree that the community is suffering from environmental degradation, which is predominantly caused by the resource industries of the community. Therefore, the resource extraction industry of the community has not blinded the residents to the environmental consequences and threats presented by the resource industry, nor has it prevented them from criticizing it. Admitting the environmental threat posed by industry is a necessary but insufficient step in any future campaign to promote the sustainable economic development of the community.

The author made comparisons between workers of KGOK and other residents of Kovdor related to statements 2-7 and 9-13 with an aim to solve whether there are differences in views between the workers of KGOK and other residents. The only differences were in the seventh question, where among the workers of KGOK the idea of the state ownership of KGOK was more popular than among the other residents of the town (Chi Square $=0.014$, almost significant result). Therefore, the paternalistic expectations towards the Russian state are more widely represented among the 
workers of KGOK because of their general expectation that the state would guarantee the development of their mining company.

\section{Discussion}

The paper showed that local-level obstacles to sustainable socio-economic development in this case study's resource community can be approached by the local resource curse theory. This was seen for example in the views representing "resource fatalism" (E3) that leads to pessimistic expectations in the community. These pessimistic expectations, caused by the volatility of resource prices, are a hindrance to initiatives at economic diversification, because of the lack of belief in the stable future well-being of the community. The current approach to development, which is based on resource extraction by external actors, creates paternalistic expectations among the residents and fails to support the long-term sustainability of the community. Hence, economic diversification needs either a change in the general attitude of the community's residents or paternalistic support from higher governmental levels, as the community itself is incapable of promoting economic diversification because of the lack of belief in the community's prospects. This shows that the path-dependency of paternalistic expectations in the community is likely to continue, instead of self-sustainable development. Therefore, it should be asked whether the residents of the resource community should approach their place of residence as a temporary space subsidized by the public authorities because the current attitudes do not promote long-term sustainability, in which an active role would be played by the locals.

Several issues which are described as common elements of the resource curse and of the staple thesis in resource communities are also common in Russian society in general and in other industrial communities in Russia. Therefore, it is difficult to say how resource-derived they are. Moreover, while the resource path is typical for resource communities, the dependency of the local development path, which defines local development, also characterizes other communities. Hence, because of the lack of comparative data from a nonresource community, the survey can only estimate to a limited extent whether the elements are purely resource-derived. More studies and a comparative case study would be needed to discuss whether there are also resource-derived factors behind the elements, which the theory does not classify as resource-derived, but which, according to previous studies, commonly characterize resource-producing regions. Nevertheless, the presence of these issues, which the theory classifies as not purely resource-derived, creates obstacles for sustainable local socio-economic development in resource-based communities.

Mainstream resource-curse studies approach resource-based development in terms of the economic impacts of the resource curse. However, this study inspires the author to argue that more attention should be paid to the structural and attitudinal consequences of resource-based development, which could enhance our understanding about the negative consequences of resourcebased development for sustainable local socioeconomic development. This study should be followed by new studies which would see resourcebased development as an obstacle to sustainable socio-economic local development in resourcebased communities, which could also improve our knowledge of the influence of resource extracting industries on elements that the study classifies as not purely resource-derived.

\section{Conclusions}

This paper sought to explain how the challenges faced by the sustainable use of local economic potential can be approached with local resource curse theory. The conclusions of the study discuss how the empirical data supports or fails to support the idea that different elements are obstacles to the sustainable use of the local economic potential and challenges for sustainable socio-economic development in the case study town of Kovdor. The conclusions discuss both the resource-derived elements and other elements.

\section{Local resource curse: resource-derived elements}

The volatility of natural resource prices (E1) impacts on Kovdor by creating a sense of general pessimism within the community. This in turn is an obstacle to the economic diversification efforts of the residents, who would have the main responsibility in any efforts at promoting small-scale economic diversification. Moreover, other obstacles come in the form of "resource fatalism" and pater- 
nalistic expectations in the community. In turn, the impact of resource abundance (E2) is difficult to analyse in the case-study community as the role of the community in the decision making related to local resources has been limited. However, the Russian state and Eurochem have supported the versatile use of the resource potential of Kovdor. Therefore, the local development path has sought to utilize the mineral versatility of the Kovdor district. Hence, there are limited negative consequences of resource abundance.

The path-dependency (E3) that supports resource-led thinking is evident in various issues, such as the views of the community as a resource producer, where alternative development is unthinkable. The path-dependency has fostered "resource fatalism" and "paternalistic expectations" in the community. Path-dependency is clearly an obstacle to sustainable local economic development because it forms an attitudinal barrier to considering alternative development paths in the community. However, the high commitment to path dependency by the survey respondents of the community may also result from the fear of dramatic changes. In the 2000s the years of stability during the resource-based development brought positive annual development. Hence, any dramatic changes might awake memories of the instabilities of the restructuring of the political and economic system during perestroika and in the 1990s.

Environmental degradation (E4), experienced by the residents, is evident in Kovdor. However, because of the absence of alternative industries, such as tourism, the environmental degradation causes limited harm to the local economic development. Hence, the negative impacts of environmental degradation are limited to its affect upon the quality of life in the community. Moreover, potential areas for the development of nature tourism in the Kovdor district are outside the environmental impact zone of the mining industries. Nevertheless, the environmental threat should be removed, given its consequences to the sustainable social development of the community.

\section{Local resource curse: other elements}

The paternalistic attitude of the federal and regional authorities towards the resource industries of Kovdor is evident (E5). Although Kovdorslyuda has been supported by the public authorities, it has had little if any positive consequences to Kovdorslyuda's economic sustainability. However, be- cause of the lack of an alternative to this public subsidizing of the community, the negative influence on the sustainable use of local resources is limited. The support of the resource industry is positive from the point of view of the community's short-term development as a resource community. However, from the point of view of the economic efficiency of the region and the country, where subsidies could be given to alternative industries instead of the resource in-dustries, the sustainability of these subsidies is questionable and prolongs Russia's resource-based development instead of fostering economic diversification. Moreover, there is a clear evidence of paternalistic expectations among the residents of Kovdor (E6). These paternalistic expectations largely prevent the residents from thinking about alternative industries in the local economy, as paternalism is expected both from the public authorities and from the resource firm. KGOK's workers have self-image of their strategic importance, which is another basis for their paternalistic expectations. These expectations of paternalism from the state are particularly evident during periods when the mining industry is experiencing an economic crisis. As these paternalistic expectations are deeply rooted in the community, it is likely that they will also manifest themselves in any alternative industries that may emerge if, for example, the public authorities provide start-up money for the diversification of the local economy. These paternalistic expectations do not encourage the long-term sustainability of the community, as the locals look to external actors for subsidies.

The limited nature of local opportunities to influence local development and the ex-traction of natural resources is evident (E7). Development is dependent on decision making by higher governance levels and the resource firm. Therefore, local decision making has a limited role in supporting potential local initiatives concerning economic diversification. However, if centrally-led policies satisfy the locals, then one must assume that they don't regard the lack of local decision making as a problem. Hence, the locals are backing the state's control of local resources by supporting the idea of greater role of the state in the ownership of KGOK. Moreover, a comparison between KGOK and Kovdorslyuda shows that Eurochem's ownership of KGOK, the local mining enterprise, has had positive consequences in contrast to the lack of a powerful vertical production chain behind Kovdorslyuda. Therefore, according to results and evidence, it 
is questionable whether more independent decision making in relation to local resources would promote local socio-economic development. Hence, changes in the development path of the local mining industry, which has been controlled by external actors from the very beginning, might lead to highly undesirable consequences, such as losing a stable external investor who guarantees stable local development. Nevertheless, the local dominance of the main firm (E8) does not have a similar negative impact for alternative industries as it would in some other communities with clearly conflicting interests between mining and alternative industries, such as tourism. However, the view of the respondents that there was lack of freedom in Kovdor when it came to starting up alternative economic activities might reflect "crowding out".

\section{NOTES}

${ }^{1}$ According to new classifications a total of 24 subjects of the Russian Federation form the territory of The Russian North. The Russian North is divided into the Far North and territories equivalent to the Far North. A total of 15 subjects of the Russian Federation belong totally or partly to the Far North category. The following subjects belong to the Far North entirely: Murmansk region, Magadan region, Kamchatka region, Republic of Sakha, Yamal-Nenets AO, Nenets AO and Chukotka AO. The following regions partly belong to Far North of Russia: Arkhangelsk region, Sakhalin region, Irkutsk region, Republic of Karelia, Komi Republic, Tuva Republic, Krasnoyarsk krai and Khabarovsk krai. The territories equivalent to the Far North consist of regions with severe climate conditions, but not as severe as in the Far North (Zakonprost 2014).

${ }^{2}$ Staples are basic commodities, such as raw materials, which form the basis of a regional or local economic culture. The so-called "staple regions" are based on the export of their staple products with low added value to these staples (Innis 1933).

3 In this paper, the concept of path dependency means a local development path based on resource extraction.

${ }^{4}$ See more about official restrictions, such as restricted permission for outsiders, in Suutarinen (2013).

\section{ACKNOWLEDGEMENTS}

The author is grateful to the Academy of Finland to its financial support for the study. The author also wishes to thank Prof. S. Fortescue and Dr. Vesa Rautio for their comments on earlier versions of the paper. In addition, the author wishes to thank the staff of the Kola Science Centre in Apatity with special mention to Dr. Vladimir Didyk for the feedback to the paper. Moreover, the author is grateful for the two anonymous reviewers for their valuable comments to the paper.

\section{REFERENCES}

51rus.org 2014. "Kovdorslyuda»: ni sokhranit', ni zatopit' - net sredstv, 20.02.2014. <http://51rus. org/news/economy/3865>03.05.2014.

Ahrend R 2005. Can Russia break the "resource curse"? Eurasian Geography and Economics 46: 8, 584-609. http://dx.doi.org/10.2747/1538-7216.46.8.584.

Ahrend R 2008. Can Russia sustain strong growth as a resource based economy? CESifo Forum 9: 2, 3-8.

Andreev S 2009. Poyavitsya li v Murmanskoi oblasti svoe Pikalevo? Komsomol'skaya Pravda (Murmansk). 13.07.2009. <http://murmansk.kp.ru/ daily/24325.5/517463/>09.01.2015.

Anokhin A, Kuznetsov S \& Lachininskii S 2014. A spatial study of geo-economic risk exposure of Russia's arctic mono-towns with commodity export-based economy. Journal of Geography and Geology 6: 1, 38-45. http://dx.doi.org/10.5539/jgg.v6n1p38.

B-Port.Com 2013. Kovdor poidut investitsii, 22.11.2013. <http://www.b-port.com/news/item/118795.html> 30.01.2014.

Barasheva T 2011. Reformirovanie munitsipal'nykh finansov: problemy i perspektivy. Vestnik Kol'skogo nauchnogo tsentra RAN 4, 52-58.

Barnes T 2005. Borderline communities. Canadian single industry towns, staples, and Harold Innis. In Van Houtum H, Kramsch O \& Zierhofer W (eds). B/ordering space, 109-122. Ashgate, Aldershot.

Blakkisrud H 2006. What's to be done with the North. In Blakkisrud H \& Hønneland G (eds). Tackling space: Federal politics and the Russian North, 25-51. University Press of America Lanham, MD, and Oxford.

Blakkisrud H \& Hønneland G 2006. The Russian North - An introduction. In Blakkisrud H \& Hønneland G (eds). Tackling space: Federal politics and the Russian North, 1-24. University Press of America Lanham, MD, and Oxford.

Bolotova A 2012. Loving and conquering nature: Shifting perceptions of the environment in the industrialised Russian North. Europe-Asia Studies 64: 4, 645-671. http://dx.doi.org/10.1080/09668136.2012.673248.

Bolotova A \& Stammler F 2010. How the North became home. Attachment to place among industrial migrants in Murmansk region. In Southcott $C$ \& Huskey L (eds). Migration in the Circumpolar North, 193-220. CCI Press, Edmonton.

Borge LE, Parmer P \& Torvik R 2013. Local natural resource curse? Working paper series, No. 11/2013. Department of Economics. Norwegian University of Science and Technology. <http:// www.svt.ntnu.no/iso/WP/2013/11_localcurse_ LEB_PP_RT.pdf $>$ 06.05.2014. 
Bradshaw M 2006. Observations on the geographical dimensions of Russia's resource abundance. Eurasian Geography and Economics 47: 6, 724-746. http://dx.doi.org/10.2747/1538-7216.47.6.724.

Bystrova I 2013. "Kovdorslyuda" v dvukh shagakh ot zakata. Kovdorchanin, 12.09.2013. <http://www. kovdorgok.ru/news/kovdorsljuda_v_dvukh_ shagakh_ot_zakata/2013-09-12-54> 05.05.2014.

Carson D \& Carson D 2011. Why tourism may not be everybody's business: The challenge of tradition in resource peripheries. The Rangeland Journal 33, 373-383. http://dx.doi.org/10.1071/RJ11026.

Connolly R 2011. Financial constraints on the modernization of the Russian economy. Eurasian Geography and Economics 52: 3, 428-459. http://dx.doi.org/10.2747/1539-7216.52.3.428.

Davis GA \& Tilton JE 2005. The resource curse. Natural resources forum 29: 3, 233-242. http://dx.doi.org/10.1111/j.1477-8947.2005.00133.x.

Didyk V 2012. Issledovanie praktiki strategicheskogo planirovaniya i upravleniya $v$ munitsipal'nykh obrazovaniyakh Severa Rossii. Regional'naya ekonomika: teoriya i praktika 23: 254, 31-38.

Didyk V \& Riabova L 2012. Trendy ekonomicheskogo i sotsial'nogo razvitiya Murmanskoi oblasti: rezul'taty monitoringa za dva desyatiletiya rynochnykh reform. Kola Science Centre RAS Publications, Apatity.

Dombrovskii L 2011. The head of KGOK's department of work and industrial safety, Former mayor of the Kovdor District. Focus group discussion with the author, 16.5.2011, Headquarters of KGOK, Kovdor, Russia.

Eilmsteiner-Saxinger G 2011. 'We feed the nation': Benefits and challenges of simultaneous use of resident and long-distance commuting labour in Russia's northern hydrocarbon industry. Journal of Contemporary Issues in Business \& Government 17: 1, 53-67.

Florida R 2005. Cities and the creative class. Routledge.

Fortescue S 2009. Putin in Pikalevo: PR or watershed? Australian Slavonic \& East European Studies 23: 1-2: 19-38.

Foxall A 2014. We have proved it, the Arctic is ours': Resources, security and strategy in the Russian Arctic. In Powell RC \& Dodds K (eds). Polar geopolitics? Knowledges, resources and legal regimes, 93-112. Edward Elgar Publishing Limited, Cheltenham.

Gaddy C \& Ickes B 2010. Russia after the global financial crisis. Eurasian Geography and Economics 51: 3, 281311. http://dx.doi.org/10.2747/1539-7216.51.3.281.

Gaddy C \& Ickes B 2013. Russia's dependence on resources. In Alexeev $\mathrm{M} \&$ Weber $\mathrm{S}$ (eds). The $\mathrm{Ox}$ ford handbook of the Russian economy, 309-340. Oxford University Press, New York.

Hayter R, Barnes TJ \& Bradshaw MJ 2003. Relocating resource peripheries to the core of economic geography's theorizing: Rationale and agenda. Area 35: 1, 15-23.

Humphreys M, Sachs J \& Stiglitz JE 2007. What is the problem with natural resource wealth? In Humphreys
M, Sachs J \& Stiglitz JE (eds). Escaping the resource curse, 1-20. Columbia University Press, New York.

IFAP 2008. Kontseptsiya dolgosrochnogo sotsial'noekonomicheskogo razvitiya Rossiiskoi Federatsii na period do 2020 goda. <http://www.ifap.ru/ofdocs/rus/rus006.pdf> 28.12.2013.

Innis HA 1933. Problems of staple production in Canada. The Ryerson Press, Toronto, ON.

Karl TL 1997. The paradox of plenty: Oil booms and petro-states. University of California Press, Berkeley, CA.

Kauppila P, Saarinen J \& Leinonen R 2009. Sustainable tourism planning and regional development in peripheries: A Nordic view. Scandinavian Journal of Hospitality and Tourism 9: 4, 424-435. http://dx.doi.org/10.1080/15022250903175274.

Khibiny.com 2010. V Kovdore nachalos' osvoenie novogo mestorozhdeniya apatit-shtaffelitovykh rud, 28.6.2010 <http://www.hibiny.com/news/ archive/19096>14.01.2014.

Khibiny.com 2012. Kovdorskii GOK investiruet sotsialn'ye proekty goroda, 13.09.2012<http:// www.hibiny.com/news/archive/36301> 03.05.2014.

Kim Y 2003. The resource curse in a post-communist regime: Russia in comparative perspective. Ashgate, London.

Kortelainen J \& Nystén-Haarala S 2009. Construction of trust in Russian mill towns. In Nystén-Haarala S \& Kortelainen J (eds). The changing governance of renewable natural resources in northwest Russia, 149-167. Ashgate, Aldershot.

Kovdorskii raion 2011. Kompleksnyi investitsionnyi plan modernizatsii monoprofil'nogo goroda Kovdor. Administration of the Kovdor district. <http:// $w w w$. kovadm.ru/Up/o a d / A t tach/72_20111028094332.doc> 02.05.2014.

Kvitko E \& Telen' L 2001. Kak MDM-grupp Kovdorskii GOK po deshevke pokupala, 12.06.2001. <http://kompromati.ru/2001/07/30/kak-mdmgrupp-kovdorskij-gok-po-deshevke-pokupalaochen-specialnyj-aukcion/> 02.05.2014.

Larichkin F 2012. The director of the Institute of ECOnomic Problems KSC RAS in Apatity. Personal communication in Apatity (Russia), 14.06.2012.

Maksheeva Yu 2010. Bogatstva Kolskoi zemli - na pol'zu lyudyam. Murmanskii Vestnik, 18.12.2010. <ht p: / / www. mvestnik.ru/shwpgn. asp?pid $=201012184734>30.01 .2014$.

Medvedev D 2009. Dmitrii Medvedev: Rossiya, vpered! Gazeta.ru, 10.09.2009. <http://www. gazeta.ru/comments/2009/09/10_a_3258568. shtml>09.01.2015.

Melin H 2005. Toward new paternalism in Kondopoga. In Melin $\mathrm{H}$ (ed). Social structure, public space and civil society in Karelia, 61-75. Kikimora Publications, Helsinki.

MinEc 2012. Informatsiya o gradoobrazuyushchei organizatsii monoprofil'nogo goroda. Ministerstvo Ekonomicheskogo Razvitiya Murmanskoi oblasti. <http://minec.gov-murman.ru/content/devel_ city/sub06/sub03/3.xIsx> 10.12.2012. 
Moi Gorod 2014. Kovdor. 24.12.2014. <http://www. mojgorod.ru/murmansk_obl/kovdor/index.html> 09.01.2015.

Nash Gradostroitel'nyi kombinat 2014. <http:// www.kovdorgok.ru/o-kovdorskom-goke.html> 06.05.2014.

Petrov AN 2008. Marginal regions in discursive space: An examination of socio-economic conditions, development paths and spatial differentiation in the economic systems of the Canadian and Russian North. Doctoral dissertation, University of Toronto.

Pilipenko N \& Sapuntsova M 2007. OAO «Kovdorskii GOK» v sisteme mineral'no-khimicheskoi kompanii «EvroKhim». Gornyi Zhurnal 9, 19-20.

Pilyasov A 2013. Russia's policies for Arctic cities. Russian Analytical Digest 129, 2-4. <http://www. css.ethz.ch/publications/pdfs/RAD-129.pdf> 05.05.2014.

Prokhorova E 2014. Reinventing a Russian mono-industrial town. From a socialist 'town of miners' to a post-socialist 'border town'. Doctoral dissertation, University of Eastern Finland.

Rautio V 2003. The potential for community restructuring: Mining towns in Pechenga. Kikimora Publications, Helsinki.

Rautio V \& Round J 2008. The challenges of going global: Industrial development in remote resource regions. In Rautio V \& Tykkyläinen M (eds). Russia's northern regions on the edge: Communities, industries and populations from Murmansk to Magadan, 112-142. Kikimora publications B:37, Helsinki.

Reisser C 2013. Corporate power and urban policy in Norilsk. Russian Analytical Digest 139, 15-19. <http://www.css.ethz.ch/publications/pdfs/ RAD-139.pdf> 05.05.2014.

Rosser A 2006. The political economy of the resource curse: A literature survey. Working paper 268. Institute of Development Studies. <http://r4d.dfid. gov.uk/PDF/Outputs/futurestate/wp268.pdf> 03.05.2014.

Sachs JD \& Warner AM 2001. The curse of natural resources. European Economic Review 45, 827-838. http://dx.doi.org/10.1016/S0014-2921(01)00125-8.

Scherbak A 2010. The impact of the oil shock on the post-Soviet regime changes. In Gel'man V \& Marganiya $\mathrm{O}$ (eds). Resource curse and post-Soviet Eurasia, 49-71. Rowman \& Littlefield Publishers, Lanham, MD.

Schmallegger D \& Carson D 2010. Is tourism just another staple? A new perspective on tourism in remote regions. Current Issues in Tourism 13: 3, 201-221. http://dx.doi.org/10.1080/13683500903359152.

Spies M 2009. Oil extraction in extreme remoteness. The organization of work and long-distance commuting in Russia's northern resourse peripheries. Doctoral dissertation, University of Joensuu.
Stammler F \& Peskov V 2008. Building a 'culture of dialogue' among stakeholders in north-west Russian oil extraction. Europe-Asia Studies 60: 5, 831-849.

Strategicheskoe partnerstvo «Severo-Zapad» 2012. Perechen' prioritetnykh investitsionnykh proektov $v$ Severo-Zapadnom federal'nom okruge, 07.02.2012. <http://www.n-west.ru/strategicheskoe-planirovanie/strategiya-szfo-2020/> 10.01.2015

Suutarinen T 2011. Arktinen 'rajakaupunki' Koutero asuinympäristönä ja kaivostoimintariippuvaisena paikkakuntana. Terra 123: 3, 127-138.

Suutarinen T 2013. Socio-economic restructuring of a peripheral mining community in the Russian North. Polar Geography 36: 4, 323-347. http://dx.doi.org/10.1080/1088937X.2013.845802.

Travin D \& Marganiya O 2010. Resource curse: Rethinking the Soviet experience. In Gel'man V \& Marganiya $\mathrm{O}$ (eds). Resource curse and Post-Soviet Eurasia, 23-47. Rowman \& Littlefield Publishers, Lanham, MD.

Tsukerman V 2012. Head of the Department of Industrial and Innovation Politics KSC RAS in Apatity. Personal communication in Apatity (Russia). 14.06.2012.

Tykkyläinen M 2010. Geography and the economic evolution of the Russian North. In Huttunen $T$ \& Ylikangas $\mathrm{M}$ (eds). Witnessing change in contemporary Russia, 250-283. Kikimora Publications B:38, Helsinki.

Tynkkynen VP 2005. Ympäristökonstruktiot periferiassa ja venäläinen resurssikirous - seuraukset suunnittelulle. Alue ja Ympäristö 34: 2, 3-14.

Tynkkynen VP 2007. Resource curse contested - Environmental constructions in the Russian periphery and sustainable development. European Planning Studies 15: 6, 853-870. http://dx.doi.org/10.1080/09654310701214549.

Van der Ploeg F 2011. Natural resources: Curse or blessing? Journal of Economic Literature 49: 2, 366-420. http://www.jstor.org/stable/23071620.

Wright G \& Czelusta J 2004. Why economies slow: The myth of the resource curse. Challenge 47: 2, 6-38.

Yusupova I 2013. Udushayushchii priem: iz-za otklyucheniya elektroenergii v OOO «Kovdorslyuda» ostanovleno proizvodstvo, Komsomol'skaya Pravda (Murmansk), 12.09.2013. <http://murmansk. kp.ru/daily/26132/3023270/>02.05.2014.

Zakonprost 2014. Perechen' raionov Krainego Severa i pripravnennykh k nim mestnostei. <http://www. zakonprost.ru/content/base/part/578672> 09.01.2015.

Åslund A 2005. Russian resources: Curse or rents? Eurasian Geography and Economics 46: 8, 610-617. http://dx.doi.org/10.2747/1538-7216.46.8.610. 